\title{
PENGARUH KEMASAN BOTOL, SUHU DAN LAMA PENYIMPANAN SIRUP EKSTRAK BAWANG TIWAI (Eleutheriana americana Merr)TERHADAP METABOLIK SEKUNDER DAN MIKROBA
}

\section{THE EFFECT OF BOTTLE, TEMPERATURE AND CIRCULAR STORAGE PACKAGING OF FLASH DRINK TIWAI EXTRACTS (Eleutheriana americana Merr) ON SECONDARY METABOLIC AND MICROBA}

\author{
Suroto Hadi Saputra, Eldha Sampepana dan Arba Susanty \\ Balai Riset dan Standardisasi Industri Samarinda \\ Jalan MT. Haryono/Banggeris No. 1 Telepon 0541732274 \\ email : surotohs.65@gmail.com
}

Diterima : 23-11-2018

Direvisi : 04-12-2018

Disetujui : 13-12-2018

\begin{abstract}
ABSTRAK
Pengemasan, suhu dan lama waktu peyimpanan, kandungan metabolik sekunder dan kapasitas antioksidan produk minuman merupakan hal yang penting untuk diperhatikan. Tujuan penelitian ini adalah untuk mengetahui jenis kemasan botol dan suhu penyimpanan terhadap kandungan metabolik sekunder, kapasitas antioksidan dan cemaran mikroba pada minuman sirup ekstrak bawang tiwai. Perlakuan penelitian ini menggunakan variasi jenis kemasan botol yaitu botol kaca transfaran yang dilapisi aluminium foil, botol coklat, botol plastik yang dilapisi aluminium foil dan variasi suhu penyimpanan : suhu ruang $\left(27^{\circ} \mathrm{C}\right.$ ), suhu $6^{\circ} \mathrm{C}$ (lemari pendingin), suhu $20^{\circ} \mathrm{C}$ (ruang $\mathrm{AC}$ ). Lama penyimpanan sirup ekstrak bawang tiwai dengan interval waktu 7, 14, 21 hari. Berdasarkan hasil penelitian dapat disimpulkan bahwa penggunaan kemasan botol A, B C dengan makin lama waktu penyimpanan dapat menurunkan total senyawa fenolik, total flavonoid dan kapasitas antioksidan minuman ekstrak bawang tiwai. Lama penyimpanan minuman ekstrak bawang tiwai mampu bertahan disimpan selama 7 hari dengan kemasan botol kaca transparan yang dilapisi aluminium foil dan botol coklat pada suhu ruang dan suhu $6^{\circ} \mathrm{C}$ (lemari pendingin).
\end{abstract}

Kata Kunci : Jenis Kemasan Botol, Suhu Penyimpanan, Minuman Sirup Bawang Tiwai, Metabolik sekunder, Antioksidan dan Mikrobiologi

\begin{abstract}
Packaging, temperature and storage time, secondary metabolic content and antioxidant capacity of beverage products are important things to note. The purpose of this study was to determine the type of bottle packaging and storage temperature on secondary metabolic content, antioxidant capacity and microbial contamination in tiwai extract extract syrup. The treatment of this study uses a variety of bottle types, namely transparent glass bottles coated with aluminum foil, chocolate bottles, $C$ plastic bottles coated with aluminum foil and variations in storage temperature: room temperature $\left(27^{\circ} \mathrm{C}\right), 6^{\circ} \mathrm{C}$ temperature (refrigerator), temperature $20^{\circ} \mathrm{C}$ (AC room) The storage time of tiwai extract extract syrup with intervals of 7, 14, 21 days. Based on the results of the study it can be concluded that the use of bottle $A, B C$ packaging with more storage time can reduce the total phenolic compounds, total flavonoids and antioxidant capacity of tiwai onion extract drinks. The storage time of tiwai onion extract drinks was able to survive for 7 days with transparent glass bottles coated with aluminum foil and chocolate bottles at room temperature and $6^{\circ} \mathrm{C}$ temperature (refrigerator).
\end{abstract}

Keywords: Bottle Packaging Types, Storage Temperature, Tiwai Onion Syrup Drinks, Secondary Metabolic, Antioxidants and Microbiology 


\section{PENDAHULUAN}

D emahaman dan kesadaran masyarakat tentang hidup sehat sangat penting, mengingat tuntutan konsumen terhadap bahan pangan (minuman) yang memiliki komposisi gizi yang baik, penampilan dan cita rasa menarik, memiliki fungsi fisiologis tertentu untuk tubuh seperti dapat menurunkan kadar kolesterol, menurunkan tekanan darah, menurunkan kadar gula darah, menurunkan kadar asam urat dan meningkatkan daya tahan tubuh. Meningkatnya kualitas produk suatu industri dapat diketahui melalui reaksi konsumen atau masyarakat terhadap produk itu sendiri (Kim et al., 2003). Kualitas produk khususnya di bidang pangan perlu dipertahankan untuk menunjang daya saing bagi pelaku usaha untuk berlomba-lomba menciptakan kualitas produknya dalam melahirkan konsep baru pada program jangka panjang (Ariani, 2004; Oktovianto, 2013). Salah satu konsep tersebut yaitu menciptakan produk pangan fungsional khususnya minuman fungsional.

Menurut Badan POM (2001), minuman fungsional merupakan salah satu pangan fungsional yang diolah secara alami maupun melalui proses, mengandung satu atau lebih senyawa yang berdasarkan kajian-kajian ilmiah dianggap mempunyai fungsi-fungsi fisiologis tertentu yang bermanfaat bagi kesehatan. Salah satu minuman fungsional adalah sirup ekstrak bawang tiwai.

Sirup ekstrak bawang tiwai adalah suatu produk minuman fungsional yang diolah dengan penambahan ekstrak bawang tiwai dan larutan gula yang bermanfaat bagi kesehatan tubuh karena mengandung beberapa senyawa metabolik sekunder. Metabolik sekunder merupakan senyawa metabolit yang tidak esensial bagi pertumbuhan organisme dan ditemukan dalam bentuk yang unik atau berbeda-beda antara spesies yang satu dan lainnya (Verpoorte R., Alfermann (2000). Kandungan senyawa metabolik sekunder pada sirup bawang tiwai antara lain total fenolik, total flavonoid, dan antibakteri (Suroto dkk, 2017).

Bawang Tiwai (Eleuteriane americana Merr) merupakan suatu tanaman herbal indemik Kalimantan Timur yang hidup di hutan yang mengandung beberapa senyawa metabolik sekunder yaitu flavonoid, alkaloid, tanin, triterpenoid, steroid glikosida, polifenol, naftakuinon (eleutherinon, isoeleutherinon, eleutheriol), sterol, plobatanin, antosianin, (Sukrasno dkk, 2006; Suroto dan Sampepana, 2007; Yanuar, 2007; Nitupulu, 2011; Subramaniam, dkk 2012; Saputra, 2017, Fauziati dan Sampepana 2017). Selain itu juga mengandung monoterpenoid, seskuiterpenoid, steroid (Puspadewi dkk, 2013).

Ekstrak bawang Tiwai dapat menurunkan tingkat kerusakan dinding bronkiolus dan alveolus paru-paru yang terkapar asap rokok (Nurliani dkk., 2012); dan mengandung senyawa antioksidan yang kuat dengan nilai IC $_{50}$ sebesar $25,3339 \mu \mathrm{g} / \mathrm{ml}$ (Kuntorini dan Astuti, 2010).

Bawang tiwai memiliki beberapa manfaat sebagai obat herbal seperti kanker payudara, penurun darah tinggi (hipertensi), diabetes mellitus, penurun kolesterol, obat jerawat dan bisul, kanker usus, mencegah stroke (Galingging, 2009).

Kandungan senyawa metabolik sekunder ini sangat rentan terhadap cahaya dan suhu yang dapat mempengaruhi kualitas produk dari sirup ekstrak bawang tiwai. Untuk itu dilakukanlah penelitian dengan tujuan mengetahui jenis kemasan botol dan suhu penyimpanan terhadap kandungan metabolik sekunder dan mikroba pada minuman sirup bawang tiwai 


\section{METODE PENELITIAN}

\section{Alat dan Bahan yang digunakan}

Peralatan yang digunakan terdiri dari spektrofotometer, oven, lemari pendingin, timbangan analitik, blender, kompor, panci, pisau dan alat proses lainnya. Bahan yang digunakan terdiri dari umbi bawang tiwai, gula, botol sampel, aluminium foil, air dan kain saring.

\section{Metode}

Penelitian ini menggunakan metode eksperimen dan analisis laboratorium. Menggunakan rancangan acak lengkap (RAL) dengan 2 faktor yaitu faktor pertama adalah jenis kemasan botol terdiri dari botol kaca putih dilapisi aluminium foil, botol kaca coklat, botol plastik putih dilapisi aluminium foil. Faktor kedua adalah suhu penyimpanan terdiri dari $6^{\circ} \mathrm{C}, 20^{\circ} \mathrm{C}$ dan suhu kamar $\left(27^{\circ} \mathrm{C}\right)$. Sampel diulang sebanyak 2 kali dan disimpan selama 21 hari. Parameter yang dianalisis pada sampel antara lain total senyawa fenolik, total flavonoid, persen penghambatan antioksidan (lama penyimpanan 2, 7, 14 dan 21 hari) dan cemaran mikroba (lama penyimpanan 2,7, dan 14 hari). Data total fenolik, total flavonoid dan persen penghambatan antioksidan yang diperoleh selanjutnya ditabulasikan dan dirata-rata untuk membandingkan antar taraf perlakuan. Data cemaran mikroba ditabulasikan untuk memperoleh gambaran jumlah cemaran mikroba yang terdapat pada sampel dan dibandingkan dengan Standar Nasional Indonesia (SNI) Sirup : SNI 3544-BSN, 2013.

\section{Tahapan Penelitian}

\section{Pembuatan ekstrak bawang tiwai}

Bawang tiwai yang telah dipisahkan dari batang, daun, kulit rusak atau yang sudah tua, akar dan kotoran lainnya dicuci, ditiriskan dan dirajang 0,3-0,5 cm menghasilkan simplisia. Timbang 200 gram simplisia bawang tiwai, masukkan ke dalam blender kemudian tambahkan air $400 \mathrm{ml}(1: 2)$ kemudian diblender hingga halus diperoleh sari bawang tiwai. Sari bawang tiwai di panaskan hingga suhu $70^{\circ} \mathrm{C}$ dan biarkan selama 20 menit. Angkat sari bawang tiwai dari kompor dan di kondisikan/dibiarkan selama 30 menit. Selanjutnya dilakukan penyaringan menggunakan kain saring dan dibantu dengan pemerasan sehingga diperoleh ekstrak bawang tiwai.

\section{Pembuatan larutan gula}

Pembuatan larutan gula dilakukan dengan cara gula pasir sebanyak $1 \mathrm{~kg}$ dimasukkan kedalam panci lalu masukkan air sebanyak 1 liter. Selanjutnya dipanaskan hingga mendidih, angkat dan dinginkaan hingga mencapai suhu $60-70^{\circ} \mathrm{C}$. Setelah dingin larutan gula siap untuk digunakan dalam pembuatan sirup ekstrak bawang tiwai.

\section{Pembuatan sirup ekstrak bawang tiwai}

Pembuatan sirup bawang tiwai dilakukan dengan cara mengukur ekstrak bawang tiwai sebanyak $400 \mathrm{ml}$ kemudian masukkan kedalam panci lalu ditambahkan larutan gula sebanyak $600 \mathrm{ml}$ lalu dipanaskan hingga mencapai suhu $70^{\circ} \mathrm{C}$ dan selanjutnya masukkan sirup ekstrak bawng tiwai kedalam botol.

\section{HASIL DAN PEMBAHASAN Total Senyawa Fenolik}

Senyawa fenolik yang mempunyai gugus hidroksil lebih banyak akan menghasilkan kandungan fenolik total yang tinggi. Total senyawa fenolik merupakan perkiraan jumlah senyawa fenolik yang terdapat dalam suatu bahan (Kusumaningati, 2009). Nilai rata-rata 
total senyawa fenolik ekstrak bawang tiwai di simpan dalam waktu 7 hari, 14 hari dan 21 hari $(\mu \mathrm{g} / \mathrm{ml})$ sebagaimana pada Gambar 1.

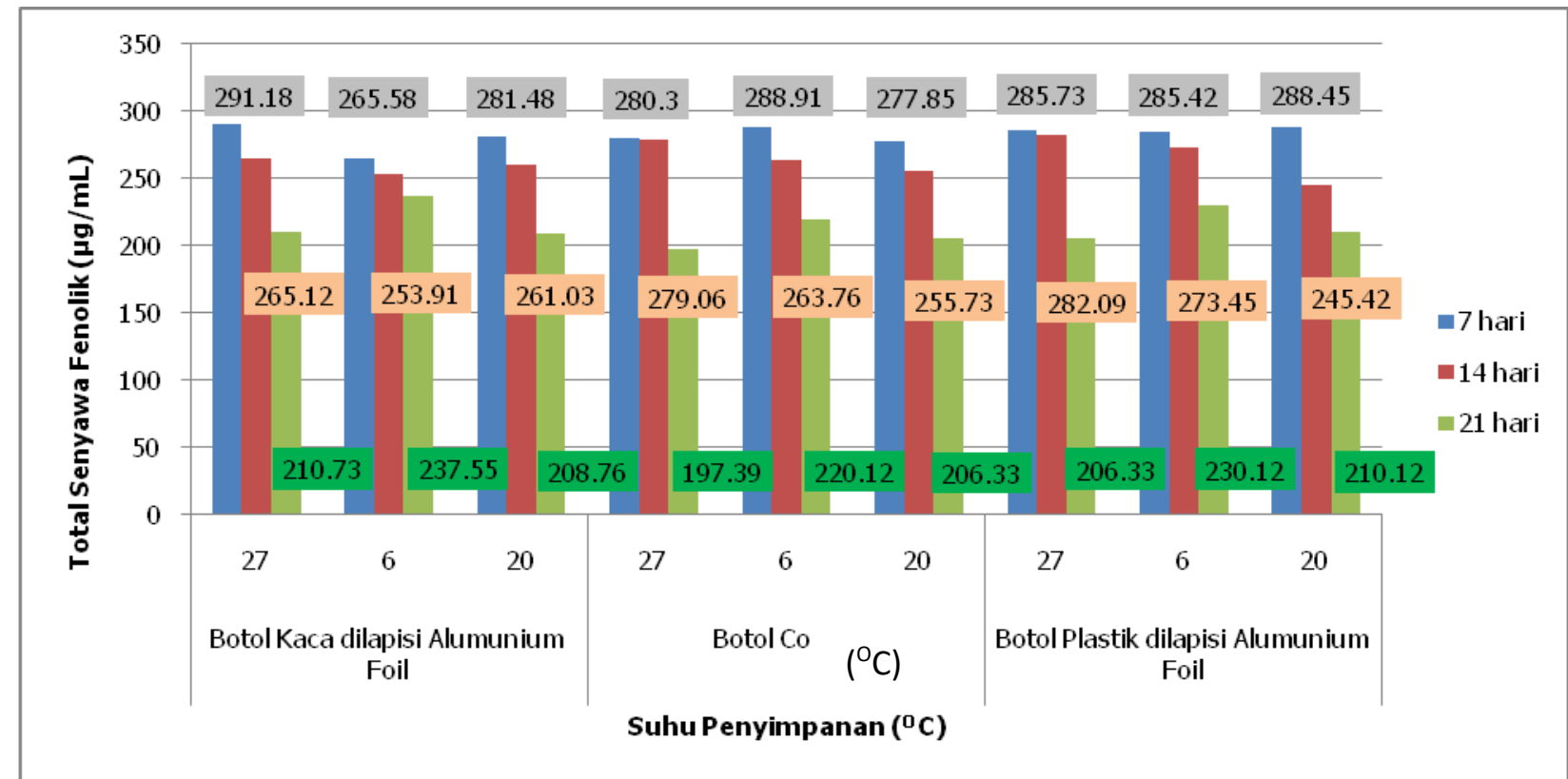

Keterangan : Total Senyawa fenolik sirup ekstrak bawang tiwai yang telah disiman selama 2 hari yaitu : 296.18 $\mu g / m L$.

Gambar 1. Pengaruh Kemasan Botol, Suhu dan Lama Penyimpanan Terhadap Kadar Total Senyawa Fenolik

Pada Gambar 1 menunjukkan bahwa nilai rata-rata total senyawa fenolik minuman sirup ekstrak bawang tiwai yang menggunakan variasi jenis kemasan botol dan suhu penyimpanan terhadap waktu penyimpanan 2,7,14 dan 21 hari mengalami penurunan. Nilai rerata total senyawa fenolik tertinggi terjadi pada semua perlakuan jenis kemasan dan variasi suhu penyimpanan yang digunakan dengan waktu penyimpanan 2 hari yaitu 296.18 $\mu \mathrm{g} / \mathrm{mL}$ dan terendah terjadi pada kemasan botol coklat disimpan pada suhu $27^{\circ} \mathrm{C}$ selama 21 hari yaitu $197.39 \mu \mathrm{g} / \mathrm{mL}$. Hal ini disebabkan karena kadar total senyawa fenolik yang ada dalam sirup ekstrak bawang tiwai mudah teroksidasi oleh cahaya, suhu penyimpanan dalam kemasan botol. Menurut Siah dkk (2011) bahwa kondisi eksternal seperti udara, suhu, cahaya pada saat penyimpanan mempengaruhi kestabilan polifenol. Total senyawa fenolik tidak dapat bertahan disimpan dalam waktu jangka lama karena dipengaruhi oleh cahaya, suhu, kemasan, waktu penyimpanan selama proses berlangsung. Penurunan nilai rata-rata total senyawa fenolik yang disimpan di suhu ruang $\left(27^{\circ} \mathrm{C}\right)$, suhu refrigator/sokist $6-8^{\circ} \mathrm{C}$ dan ruangan $\mathrm{AC}\left(20^{\circ} \mathrm{C}\right)$ mengalami penurunan karena selama proses penyimpanan terjadi reaksi polimerisasi dan degradasi komponen senyawa kimia (Tristantio dkk., 2015).

\section{Total Flavonoid}

Nilai rata-rata total senyawa flavonoid sirup ekstrak bawang tiwai yang disimpan dengan lama penyimpanan 2, 7, 14 dan 21 hari mengalami penurunan sebagaimana pada Gambar 2. 


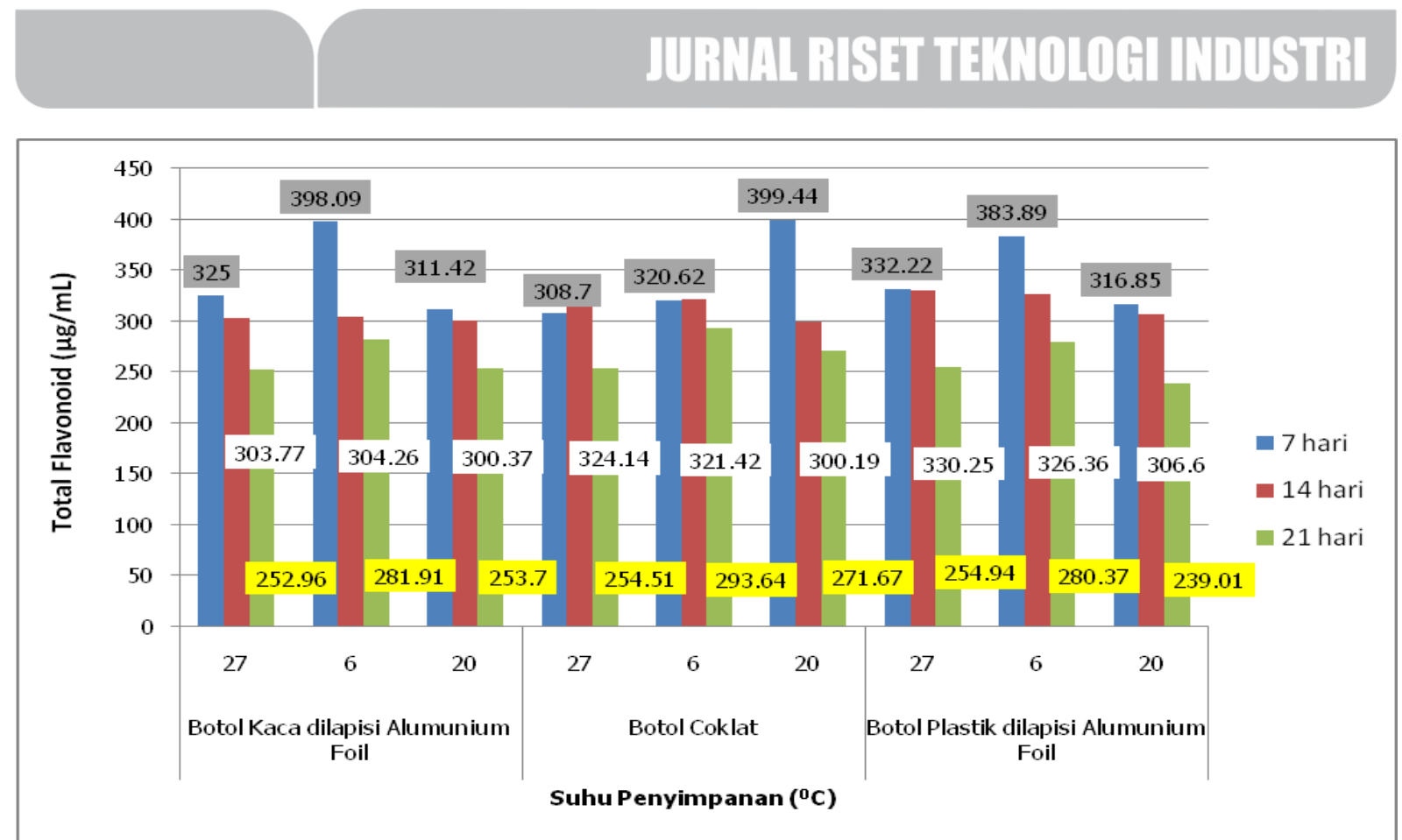

Keterangan : Total flavonoid sirup ekstrak bawang tiwai yang telah disiman selama 2 hari yaitu : $399.85 \mu \mathrm{g} / \mathrm{mL}$.

Gambar 2. Pengaruh Kemasan Botol, Suhu dan Lama Penyimpanan Terhadap Kadar Total Senyawa Fenolik

Hal ini diduga bahwa total senyawa flavonoid tidak dapat bertahan disimpan dalam waktu jangka lama. Berdasarkan Gambar 2 dapat diketahui bahwa total senyawa flavonoid mengalami penurunan baik pada suhu ruang, suhu $20^{\circ} \mathrm{C}$ dan $6^{\circ} \mathrm{C}$ serta waktu penyimpanan sangat berpengaruh. Nilai rerata total flavonoid yang tertinggi terjadi pada semua perlakuan kemasan botol yang digunakan di hari kedua yaitu $399,85 \mu \mathrm{g} / \mathrm{mL}$ dan terendah pada perlakuan kemasan botol kaca dilapisi alumunium foil dihari ke 21 yaitu 239,01 $\mu \mathrm{g} / \mathrm{mL}$. Semakin lama waktu penyimpanan semakin menurun total flavonoid. Penurunan total flavonoid ini dapat diakibatkan suhu, waktu dan cahaya selama penyimpanan karena ada beberapa senyawa seperti senyawa kuersetin dan kaempferol merupakan komponen flavonoid yang bersifat tidak stabil terhadap perubahan suhu (Ayoma \& Yamamoto, 2007).

Menurut Hahlbrock (1981) bahwa flavonoid adalah senyawa yang terdiri dari 15 atom karbon yang umumnya tersebar di dunia tumbuhan. Flavonoid merupakan senyawa fenolik yang dimiliki oleh sebagian besar tumbuhan hijau dan biasanya terkonsentrasi pada biji, buah, kulit buah, kulit kayu, daun, dan bunga (Miller, 1996). Flavonoid merupakan senyawa polar, umumnya flavonoid larut dalam pelarut polar seperti metanol, etanol, butanol, dan air. Adanya gula yang terikat pada flavonoid cenderung menyebabkan flavonoid lebih mudah larut dalam air (Markham, 1988). Berdasarkan hasil pengujian golongan flavonoid, menunjukkan ekstrak bahan alam mengandung senyawa flavonol dan flavon (Wijono 2003).

\section{Aktivitas Antioksidan (\% Inhibitis)}

Nilai rata-rata aktivitas antioksidan sirup ekstrak bawang tiwai yang disimpan dengan lama penyimpanan 2, 7, 14 dan 21 hari mengalami penurunan sebagaimana pada Gambar 3. 


\section{JURWAL RISET TEKOLOH INDUSTRI}

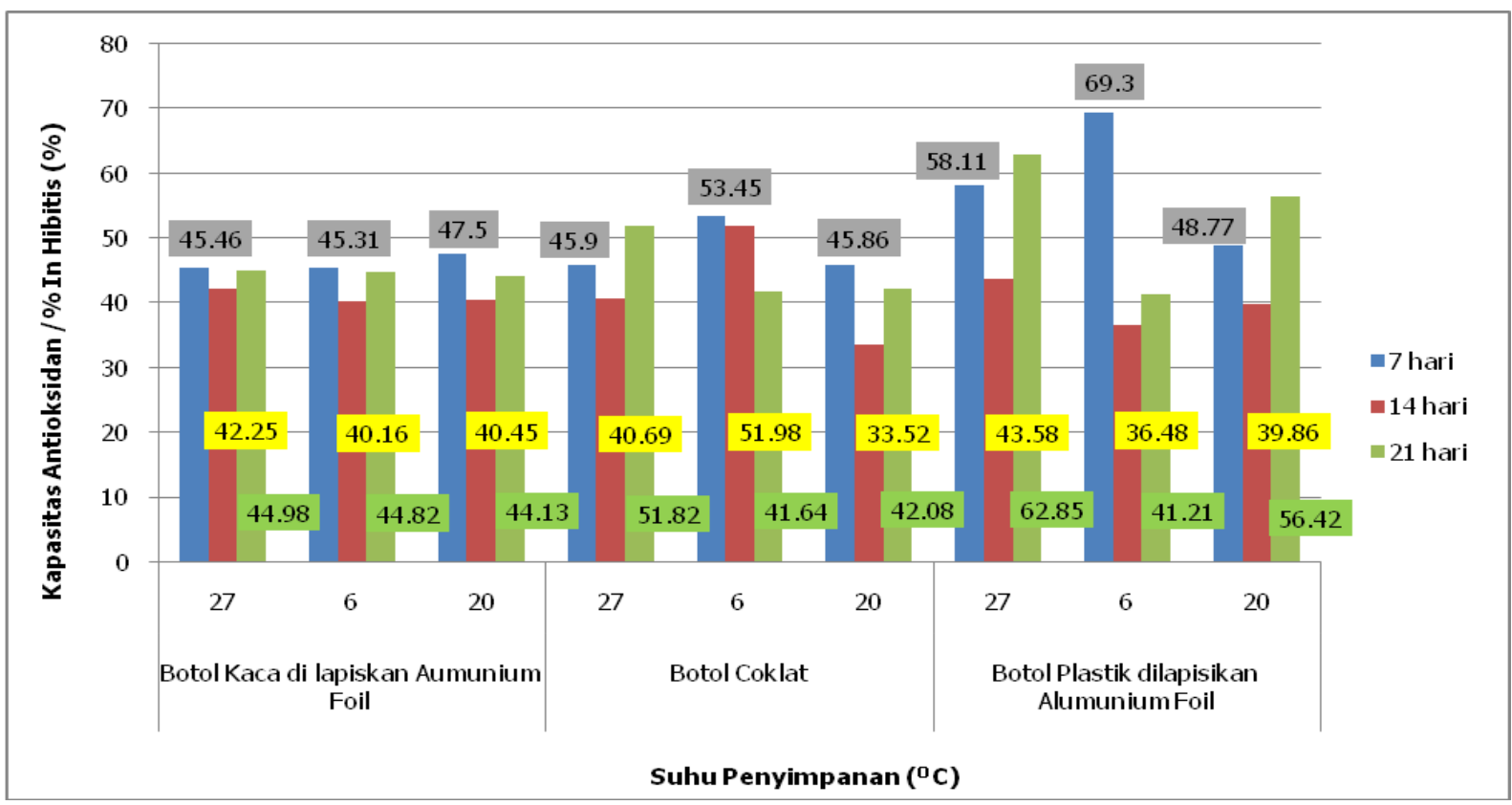

Keterangan : Kapasitas Antioksidan (\% Inhibitis) sirup ekstrak bawang tiwai yang telah disiman selama 2 hari yaitu : $69,47 \%$

Gambar 3. Pengaruh Kemasan Botol, Suhu dan Lama Penyimpanan Terhadap Aktivitas Radikal Bebas

Aktivitas antioksidan mengalami penurunan diakibatkan total senyawa fenolik dan total senyawa flavonoid yang terdapat pada sirup ekstrak bawang tiwai tidak dapat bertahan disimpan dalam waktu jangka lama. Nilai rerata aktivitas antioksidan / \% inhibitis sirup ekstrak bawang tiwai tertinggi terjadi pada perlakuan semua jenis kemasan botol, variasi suhu penyimpanan selama 2 hari yaitu $69,47 \%$ dan terendah terjadi pada kemasan botol coklat dengan suhu penyimpanan $20^{\circ} \mathrm{C}$ selama 14 hari yaitu $33,52 \%$. Terjadinya penurunan aktivitas antioksidan disebabkan karena suhu, waktu penyimpanan. Berdasarkan hasil uji aktivitas antioksidan, total fenolik, dan total flavonoid dapat dikatakan bahwa ekstrak bawang tiwai tidak stabil terhadap adanya perubahan suhu. Penurunan kapasitas antioksidan diakibatkan karena rendahnya nilai total fenol sirup ekstrak bawang tiwai pada hari kedua yaitu $69,47 \%$. Selain itu, aktivitas antioksidan juga dapat dipengaruhi oleh beberapa senyawa antara vitamin, alkaloid, saponin, flavonoid, kuinon dan tannin.

Menurut Pinheiro \& Justino (2012) bahwa senyawa flavonoid dan fenolik merupakan salah satu metabolit sekunder yang bertanggung jawab terhadap aktivitas antioksidan. Aktivitas antioksidan pada senyawa flavonoid, senyawa fenolik tersebut adalah senyawasenyawa fenol, yaitu senyawa dengan gugus $-\mathrm{OH}$ yang terikat pada karbon cincin aromatik. Senyawa fenol mempunyai kemampuan untuk menyumbangkan atom hidrogen, sehingga radikal DPPH dapat tereduksi menjadi bentuk yang lebih stabil. Dijelaskan oleh Pereira et al., (2009) bahwa senyawa bioaktif dan antioksidan seperti fenol, flavonoid, tanin, steroid, alkaloid banyak terdapat pada bawang dayak. Senyawa - senyawa tersebut memiliki kemampuan antioksidan yang dapat menghambat dan mereduksi radikal bebas.

Rendahnya kapasitas antioksidan sirup ekstrak bawang tiwai disebabkan karena adanya proses pemanasan saat pembuatan sirup bawang tiwai yang mengakibatkan senyawa metabolik sekunder bawang tiwai yaitu tannin terurai menjadi senyawa pyrogallol dan $\mathrm{CO}_{2}$ dan senyawa antosianin terdekomposisi dari bentuk aglikon menjadi kalkon (tidak berwarna) (Arisasmita dkk, 1997) dan selanjutnya menjadi alfadiketon (berwarna coklat) (Nadya dkk, 2016) 


\section{Mikrobiologi}

Pada Tabel 1 menampilkan hasil pengujian mikrobiologi minuman ekstrak bawang tiwai waktu simpan 2 Hari.

Tabel 1. Mikrobiologi Minuman Ekstrak Bawang Tiwai Waktu Simpan 2 hari

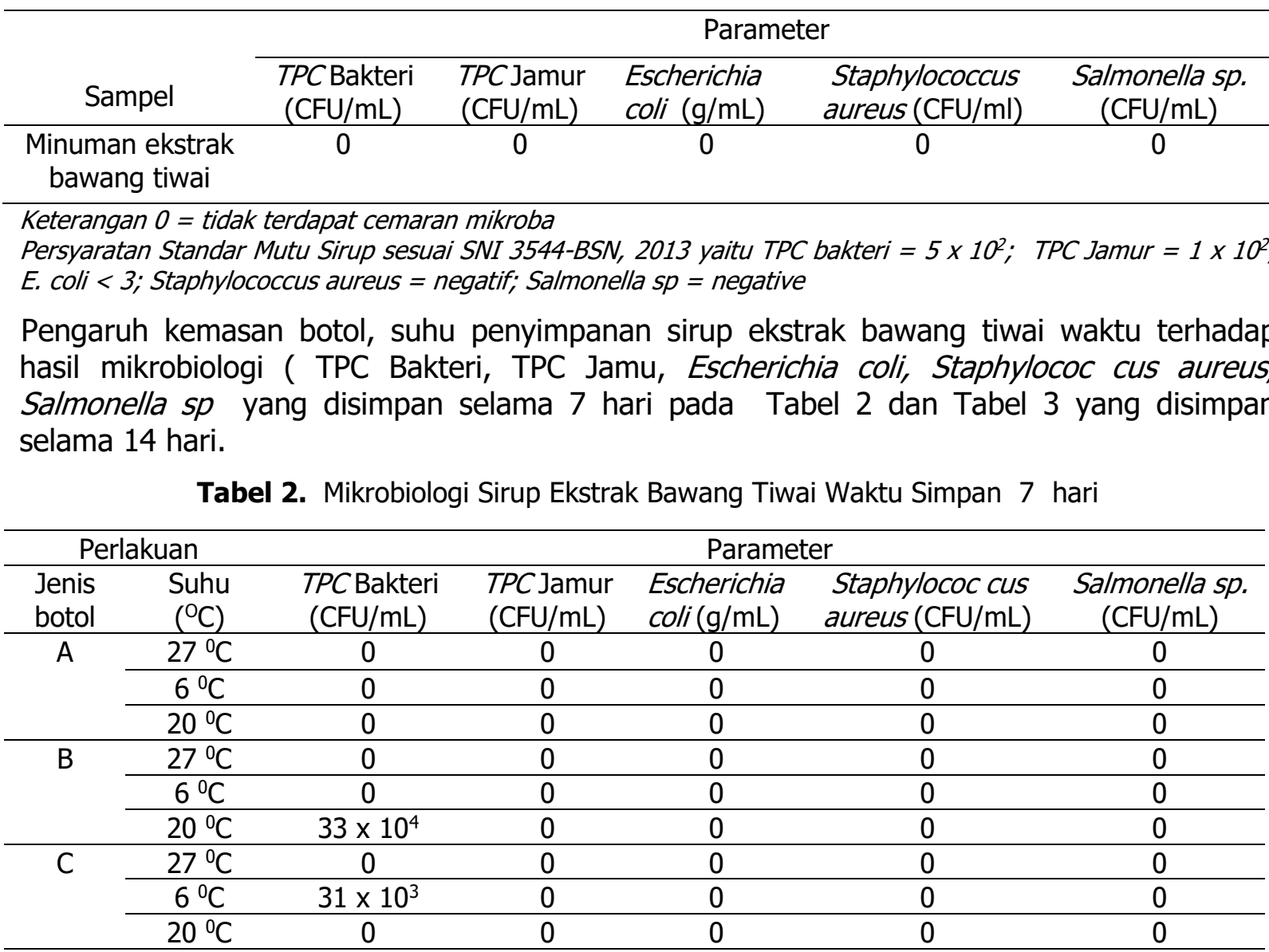

Keterangan 0 = tidak terdapat cemaran mikroba

Persyaratan Standar Mutu Sirup sesuai SNI 3544-BSN, 2013 yaitu TPC bakteri $=5 \times 10^{2} ;$ TPC Jamur $=1 \times 10^{2}$; E. coli < 3; Staphylococcus aureus = negatif; Salmonella $s p=$ negatif

Tabel 3. Mikrobiologi Minuman Ekstrak Bawang Tiwai Waktu Simpan 14 hari

\begin{tabular}{ccccccc}
\hline \multicolumn{2}{c}{ Perlakuan } & \multicolumn{5}{c}{ Parameter } \\
\hline $\begin{array}{c}\text { Jenis } \\
\text { botol }\end{array}$ & $\begin{array}{c}\text { Suhu } \\
\left({ }^{\circ} \mathrm{C}\right)\end{array}$ & $\begin{array}{c}\text { TPC Bakteri } \\
(\mathrm{CFU} / \mathrm{mL})\end{array}$ & $\begin{array}{c}\text { TPC Jamur } \\
(\mathrm{CFU} / \mathrm{mL})\end{array}$ & $\begin{array}{c}\text { Escherichia } \\
\text { coli }(\mathrm{g} / \mathrm{mL})\end{array}$ & $\begin{array}{c}\text { Staphylococ Cus } \\
\text { aureus }(\mathrm{CFU} / \mathrm{mL})\end{array}$ & $\begin{array}{c}\text { Salmonella sp. } \\
(\mathrm{CFU} / \mathrm{mL})\end{array}$ \\
\hline \multirow{2}{*}{$\mathrm{A}$} & $27^{\circ} \mathrm{C}$ & 0 & $63 \times 10^{6}$ & 4 & 0 & 0 \\
\cline { 2 - 7 } & $6^{\circ} \mathrm{C}$ & $39 \times 10^{6}$ & 0 & 17 & 0 & 0 \\
\cline { 2 - 7 } & $20^{\circ} \mathrm{C}$ & 0 & $43 \times 10^{6}$ & 6 & 0 & 0 \\
\hline \multirow{3}{*}{$\mathrm{2}{ }^{\circ} \mathrm{C}$} & $30 \times 10^{6}$ & $86 \times 10^{6}$ & 15 & 0 & $38 \times 10^{3}$ \\
\cline { 2 - 7 } & $6^{\circ} \mathrm{C}$ & $52 \times 10^{6}$ & $21 \times 106$ & 240 & 0 & $149 \times 10^{3}$ \\
\cline { 2 - 7 } & $20^{\circ} \mathrm{C}$ & $169 \times 10^{6}$ & $18 \times 106$ & 44 & 0 & 0 \\
\hline $\mathrm{C}$ & $27^{\circ} \mathrm{C}$ & $14 \times 10^{6}$ & $27 \times 10^{6}$ & 35 & 0 & $300 \times 10^{3}$ \\
\cline { 2 - 7 } & $6^{\circ} \mathrm{C}$ & $68 \times 10^{6}$ & $41 \times 10^{6}$ & 20 & 0 & 0 \\
\cline { 2 - 7 } & $20^{\circ} \mathrm{C}$ & $77 \times 10^{6}$ & $18 \times 10^{6}$ & $>1100$ & 0 & 0 \\
\hline
\end{tabular}

Keterangan 0 = tidak terdapat cemaran mikroba.

Persyaratan Standar Mutu Sirup sesuai SNI 3544-BSN, 2013 yaitu TPC (Total Plate Count) bakteri $=5 \times 10^{2} ;$ TPC

( Total Plate Count) Jamur $=1 \times 10^{2} ;$ E. coli $<3$; Staphylococcus aureus = negatif; Salmonella $s p=$ negative 
Berdasarkan nilai rata-rata hasil analisa cemaran mikroba minuman ekstrak bawang tiwai dengan waktu penyimpanan 2 hari pada tabel 1 dan penyimpanan 7 hari pada tabel 2 menunjukkan bahwa penggunaan kemasan botol kaca transparan dilapisi alumunium foil $(A)$, kemasan botol coklat (B) dan kemasan botol plastik dilapisi alumunium foil (C) dengan suhu penyimpanan di suhu ruang, suhu $6^{\circ} \mathrm{C}$ (lemari pendingin) dan suhu $20^{\circ} \mathrm{C}$ (ruang $\mathrm{AC}$ ) terhadap waktu penyimpanan selama 2 hari dan 7 hari tidak terdapat adanya cemaran mikroba TPC (bakteri), TPC (jamur), E coli, $S$. aureus, Salmonella kecuali pada kemasan botol kaca gelap dengan suhu $6^{\circ} \mathrm{C}$ dan kemasan plastik dilapisi alumunium foil dengan suhu $6^{\circ} \mathrm{C}$ dan umur simpan 14 hari adanya cemaran TPC (bakteri).

Hal ini disebabkan karena sirup ekstrak bawang tiwai mengandung beberapa senyawa metabolik sekunder yang dapat berfungsi sebagai bahan antj jamur, antibakteri, antimikroba, antiviral dan antiparasit. Menurut Kuntorini dan Nugroho (2010) dalam Christoper (2017) bahwa senyawa aktif seperti fenol, polifenol, naftokuinon (eleutherin, eleutherol, isoeleutherine), golongan kuinon yang berfungsi sebagai antimikroba, anti jamur, antiviral / antivirus dan antiparasit. Fauziati dan Sampepana (2017) menyatakan bahwa ekstrak air bawang tiwai segar mengandung senyawa aktif 3,4-dimethoxy-6-formy12,2, bipyridine berfungsi sebagai antibakteri.

Menurut Puspadewi, dkk (2013) menyatakan bahwa ekstrak bawang tiwai dengan pelarut etanol dapat menghambat Staphylococcus aureus sangat kuat dimana konsentrasi hambat minimum (KHM) $1 \%$ dengan diameter hambat $(14,49 \pm 0,51) \mathrm{mm}$ dan berpotensi sama dengan Tetrasiklin $\mathrm{HCl}$ pada konsentrasi $0,06 \%$ dengan daya hambat $14,03 \pm 0,42$ ) $\mathrm{mm}$.

Berdasarkan nilai rata-rata mikrobiologi minuman ekstrak bawang tiwai waktu simpan 7 hari dengan bakteri TPC (Total Plate Count) pada tabel 2 pada kemasan botol kaca dilapisi alumunium foil dengan suhu $20^{\circ} \mathrm{C}$ (ruang $\mathrm{AC}$ ) sebanyak $33 \times 10^{4}$ dan kemasan botol plastik dilapisi aluminium dengan suhu $6^{\circ} \mathrm{C}$ sebanyak $31 \times 10^{3}$. Tabel 3, nilai rata-rata mikrobiologi minuman ekstrak bawang tiwai waktu umur simpan 14 hari dengan bakteri TPC (Total Plate Count) bakteri, TPC ( Total Plate Count) Jamur, Escheria coli, Salmonela menghasilkan jumlah mikroba diatas baku mutu SNI Sirup, hal ini diduga karena kemampuan senyawa aktif dalam sirup ekstrak bawang tiwai mulai berkurang atau mulai melemah dalam proses penghambatannya. Hal ini juga dinyatakan oleh Mujipradhana dkk (2018) bahwa ekstrak kasar etanol, fraksi methanol, fraksi kloroform dan frksi n-heksan efektif menghambat mikroba Staphylococcus aureus dan Escheria coli dengan katergori sedang.

\section{KESIMPULAN DAN SARAN}

Berdasarkan hasil penelitian dapat disimpulkan bahwa penggunaan kemasan botol kaca dilapisi alumunium foil, botol coklat dan suhu ruang dengan penyimpanan $6^{\circ} \mathrm{C} .20^{\circ} \mathrm{C}$, selama penyimpanan dapat menurunkan total fenolik, total flavonoid dan kapasitas antioksidan minuman ekstrak bawang tiwai. Lama penyimpanan ekstrak bawang tiwai mampu bertahan disimpan selama 7 hari dengan kemasan botol kaca transparan dilapisi aluminium foil dan botol coklat pada suhu kamar dan suhu $6^{\circ} \mathrm{C}$ (lemari pendingin). Kemasan sirup ekstrak bawang tiwai menggunakan botol kaca transfaran yang dilapisi aluminium foil dan botol coklat disimpan pada suhu kamar dan suhu $6^{\circ} \mathrm{C}$.

\section{DAFTAR PUSTAKA}

Ariani, D.W. 2004. Pengendalian kualitas statistik pendekatan kuantitatif dan managemen kualitas. Yogyakarta : ANDI.

Arisasmita J. H., Indah K., Lily T. 1997. Ektstraksi dan karakteristik zat warna kulit buah manggis (Gracinia mangostana L.). Prosiding Seminar Teknologi Pangan. Jurusan 
Teknologi Pangan dan Gizi. Fakultas Teknologi Pertanian. Universitas Katolik Widya Mandala. Surabaya.

Ayoma S and Yamamoto Y. 2007. Antioxidant activity and flavonoid content of welsh onion (Allium fistulosum) and the effectof thermal treatment. Food Sci. Technol. Res. 13 (1). pp. 67-68.

Badan Pengawas Obat dan Makanan, 2001. Pengawasan klaim dalam label dan iklan pangan olahan. Badan Pengawas dan Obat dan Makanan Republik Indonesia, Jakarta.

Badan Standardisasi Nasional, 2013. Sirup, Standar Nasional Indonesia 3544, Jakarta.

Christoper W., Natalia D., Rahmayanti S., 2017. Uji aktivitas antijamur ekstrak etanol umbi bawang dayak (Eleutherine americana (Aubl.) Merr. Ex K. Heyne.) terhadap Trichophyton mentagrophytes secara in Vitro. Jurnal Kesehatan Andalas 6 (3) pp 685689. http://jurnal.fk.undad.ac.id

Fauziati dan Sampepana E. 2017. Teknologi pembuatan pewarna alam dari bawang tiwai. Teknologi Penangan Pasca Panen Umbi Bawang Tiwai dan Aplikasi di Industri. Balai Riset dan Standardisasi Industri Samarinda. Samarinda.

Galingging R.Y. 2009. Bawang dayak (Eleutherine palmifolia L. Merr) sebagai tanaman obat multi fungsi. Warta Penelitian dan Pengembangan Badan Penelitian dan Pengembangan Pertanian.2009;15:10-16.

Hahlbrock K. 1981. Flavonoids. The Biochemistry of Plants Vol. 7 : Secondary Plant Product. NewYork : Akademic Press. Hal. 425-456. http://id.m.wikipedia.org

Kim D.J., Lee, Ferrin.D.L., dan Rao H. R. 2003. Antecendents of consumer trust in B-to-C electronic commerce, Proceedings of Ninth Americans Conference on Information Systems, pp. 157-167.

Kuntorini E.M., dan Nugroho H. L., 2010. Structural development and bioactive content of red bulb plant (Eleutherine americana); aTraditional Medicines for Local Kalimantan People. Biodibersitas 11. pp. 102-106.

Kuntorini E.M dan Astuti M. D. 2010. Penentuan Aktivitas antioksidan ekstrak etanol bulbus bawang dayak (Eleutherine americana Merr.). Sains dan Teraan Kimia 4(1). pp 1522.Banjarbaru.

Kusumaningati R.W. 2009. Analisa kandungan fenol total jahe (Zingiber officinale Rosc.) secara in vitro. Jakarta: Fakultas Kedokteran. Universitas Indonesia.

Markham, R.K. 1988. Cara mengidentifikasi flavonoid. ITB. Bandung.

Miller, Alan N.D., 1996, Antioxidant flavonoid structural usage alternative medical Review I (2). 103-111.

Mujipradhana V.N., Wenengkan D.S., dan Suryanto E., 2018. Aktivitas antimikroba dari ekstrak ascidian (Hermania momus) pada mikroba pathogen manusia. Jurnal Ilmiah Farmasi, UNSRAT, Vol 7 (3) Agustus, pp. 338-347. Manado.

Nadya A.F., Chairul S, dan Erwin. 2016. Ekstraksi dan uji stabilitas zat warna dari kulit buah alpukat (Parsea americana mill.) dengan metode spektrofotometri UV-Vis. Jurnal Anatomik. Volume 01(1), pp. 23-27.

Napitupulu R. M., 2011. Isolasi dan karakterisasi senyawa flavonoid umbi dari tumbuhan bawang sabrang (Eleutherine palmifolia (L.) Merr). Skripsi. Program Ekstensi Sarjana Farmasi . Fakultas Farmasi. Universitas Sumatera Utara. Medan.

Nurliani A., Santoso H.B., Rusmiati., 2012. Efek antioksidan ekstrak bulbus bawang dayak (Eleutherine palmifolia) pada gambaran histopatologis paru-paru tikus yang dipapar asap rokok. Bioscientiae, 9(1), pp. 60-69. Banjarbaru.

Oktovianto. 2013. Analisis kecacatan produk aqua dalam upaya perbaikan kualitas dengan metode DMAIC (Studi Kasus : PT. Aqua Golden Mississipi), Universitas Pakuan Bogor. Bogor. 
Pereira D.M., Valentao P., Pereira J.A. and Andrade P.B. 2009. Phenolics: from chemistry to biology. Molecules 14, $2202-2211$.

Pinheiro, P.F., \& Justino, G.C., 2012, Structural analysis of flavonoids and related compounds-a review of spectroscopic application, Technical University of Lisbon Portugal, Portugal.

Puspadewi R. Adirestuti P., Menawati R., 2013. Khasiat umbi bawang dayak (Eleutherine palmifolia (L) Merr.) sebagai herbal antimikroba kulit. Kartika Jurnal Ilmiah Farmasi, Des 1 (1), pp.31-37.

Saputra S.H., 2017. Senyawa metabolik, bahan aktif dan manfaat bawang tiwai (Eleutheriane americana Merr.). Teknologi Penangan Pasca Panen Umbi Bawang Tiwai dan Aplikasi di Industri. Deepublish (Grup penerbitan CV. Budi Utama), Yogyakarta.

Siah, W. M., Farida H. Rahimah, Tahir S.M, and Zain D. M.2011. Effects of packaging materials and storage on total phenolic content and antioxidant activity of contella asiatica drinks, Journal of Tropical Agriculture and Food Science. 39 (1): 1-7.

Subramaniam, K., Sembian, S., Femina, W., Febrina, B.S. dan Gilbert, R.R. 2012. Antagonistic activity of eleutherine palmifolia Linn. Asian Pacific Journal of Tropical Disease. S 491-493.

Sukrasno, Urnemi dan Sadaruddin. 2006. Penelitian obat-obatan tradisional mikropropagasi dan pengembangan bawang tiwai (Eleutherine americana L.) sebagai obat herbal. ITB. Bandung.

Suroto dan Sampepana, 2007. Analisis kandungan kimia dan pemanfaatan bawang tiwai untuk bahan baku industri. Jurnal Riset Teknologi Industri Vol.1. No.1 Juni. pp. 17-24.

Suroto H.S., Susanty A., Sampepana E., Yustini P.E., Prasetyo I., Nurlina S., Sari N. I., 2017. Pengembangan ekstrak bawang tiwai secara in vivo sebagai minuman fungsional antioksidan. Laporan Penelitian. Balai Riset dan Standardisasi Industri Samarinda.

Tristanto N. A., Budianta T. D. W., Utomo A.R., 2015. Pengaruh suhu penyimpanan dan proporsi teh hijau: bubuk daun kering stevia (Stevia rebaudiana) terhadap aktivitas antioksidan minuman teh hijau stevia dalam kemasan botol plastik. Journal of Food Technology and Nutrition Vol 16 (1): pp 22-29.

Verpoorte R., Alfermann (2000). Metabolic engineering of Plant Secondary metabolism. Springer. pp. 1-3. ISBN 978-0-7923-6360-6.

Wijono, Sri Harsodjo. 2003. Isolasi Identifikasi Flavonoid pada Daun Katu (Sauropus androgynus (L.) Merr). Makara Sains. 7(2). 51-64.

Yanuar. 2007. Bawang Dayak (Eleutheriane Americana Merr) untuk Obat Kanker. www.indonesia .com (diakses tanggal 17 November 2017). 